Open Access

\title{
Entrepreneurship in small agricultural quick-impact enterprises in Iran: development of an index, effective factors and obstacles
}

\author{
Kurosh Rezaei-Moghaddam ${ }^{*}$ and Hoda Izadi
}

\author{
* Correspondence: $d r$. \\ rezaeimoghaddam@gmail.com; \\ rezaei@shirazu.ac.ir \\ Department of Agricultural \\ Extension and Education, School of \\ Agriculture, Shiraz University, Shiraz, \\ Iran
}

\begin{abstract}
Small enterprises are one of the most effective factors in the development of each country's economic and social systems, having the ability to compete with large industries, so these enterprises are mainly focused by authorities. This study aimed to develop indicators of entrepreneurship in rural small enterprises as well as identifying the effective factors and obstacles to provide strategies of entrepreneurship development. The population of study included small business owners in Fars Province, Iran that initiated business in rural areas through quick-impact enterprises project. Developing entrepreneurship index was conducted using the Delphi method and was tested using survey method. Data were gathered through interviews and questionnaires. According to the results of study, entrepreneurship development index in quick-impact enterprises includes 11 components affected by individuals, organizations and environment. Based on the results, management skills, knowledge management, business environment, self-managed training, and government policies are predictors of changes of entrepreneurship development in quick-impact enterprises. Additionally, factor analysis indicated five obstacles in development of entrepreneurship in quick-impact enterprises, including financial problems, market orientation, weakness of information, poor and inappropriate business environment and weakness in supportive government policies. Finally, some applicable recommendations were presented based on the study results.
\end{abstract}

Keywords: Entrepreneurship development, Index, Quick-impact enterprises, Agriculture, Iran

\section{Introduction}

Entrepreneurship is one of the most important economic growth and development factors of countries. The mechanism of entrepreneurship and its effects on the performance of countries are less known (Thurik and Wennekers, 2004). Entrepreneurship creates new opportunities for entrepreneurs to increase their income and assets. In addition, by creation of new institutions and small and medium businesses, it improves living standards (Henley, 2005). Despite many studies, there is a debate on definition of entrepreneurship and entrepreneur (Davidsson et al., 2001). In recent years, entrepreneurship has become a term that has been primarily focused by politicians and they refer to its importance, while the entrepreneurship quality and policies have been less

(c) The Author(s). 2019 Open Access This article is distributed under the terms of the Creative Commons Attribution 4.0 International License (http://creativecommons.org/licenses/by/4.0/), which permits unrestricted use, distribution, and reproduction in any medium, provided you give appropriate credit to the original author(s) and the source, provide a link to the Creative Commons license, and indicate if changes were made. 
focused (Ahmad and Hoffmann, 2008). Sometimes self-employed person by criterion of non-payment of wages by individuals or organizations is considered as entrepreneur and the entry rate of these companies as entrepreneurship (Gartner and Shane, 1995). Bird (1988) considers entrepreneurship process by focus on the opportunity of a strategic process with the ability to make quick decisions in a changing or flexible environment (Bird, 1988). Ireland et al. (2003) argue entrepreneurship process is linear and sequential that includes mind of the entrepreneur, management of resources to deal with the situation, creativity, innovation and competitive advantage. People may choose a business different from the one they were socialized into (Chakraborty et al., 2016).

According to entrepreneurship characteristics, there is a range of indices rooted on different variables. Coduras et al. (2016) argue the main variables of entrepreneurial profiles have been grouped into three categories including sociological, psychological and managerial-entrepreneurial. The concept of entrepreneurship initiated from economic schools and it was extended to psychology, sociology and management schools. There are differences in the definitions of entrepreneurship among researchers of a particular school, a difference that can be seen in ideas of Kirzner and Schumpeter (Metcalfe, 2004). Kirzner discuss that some people identify existing information in the market (Shane, 2000). Schumpeter contend that opportunities are created by entrepreneurs (Hayton et al., 2011). An opportunity has been seen as a result of creative ability of an individual who introduces innovations to the market (Scheiner, 2014).

Measurement of entrepreneurship is difficult, because it is a multi-dimensional concept (Wang et al., 2015). Due to the various definitions and measurements, entrepreneurship is a multifaceted concept (Iversen et al., 2008), while specifying entrepreneurs' share of economic prosperity dependents on the perception of entrepreneurship actions within the specified time framework (Gartner and Shane, 1995). Thus, creating entrepreneurship quality index leads to identification a wide range of effective economic, social, political and organizational factors that have impact on entrepreneurship with high quality. Measurement of entrepreneurship quality would be enabled researchers to explore the critical role of high quality entrepreneurship in economic growth in general and rural development in particular (Cheng et al., 2009).

\section{Review of literature}

Many studies have been conducted on entrepreneurship of small businesses, whereas some issues have remained unknown still. Previous studies have provided evidences for distinguishing between self-employment, business ownership, new business creation and entrepreneurship (Urbano and Aparicio, 2016). However, it is just less studies to develop a special index for entrepreneurship of small business in general and particularly in small agricultural enterprises due to the literature. Hjorth and Holt (2016) focused on social side of entrepreneurship and argue that entrepreneurship is different from enterprise, as the management is not leadership. Although there is an overlapping among definitions of entrepreneurship and creation of small businesses; small businesses are not always entrepreneurship companies and their owners are not always entrepreneurs (Carland et al., 1984). Small firms are more frequent incubators of entrepreneurs due to less hierarchical. Hierarchy is less prevalent in small businesses and is associated with more frequent transitions of employees into self-employment 
and entrepreneurship (Tåg et al., 2016). Reviewing previous studies, it is required to improve and develop the measurement methods of entrepreneurship and small businesses (Wang et al., 2015), because there is no comprehensive framework regarding the entrepreneurship process components. Thus, more entrepreneurship studies require for theory development (Davidsson et al., 2001). In any definition, entrepreneurship is a behavior and a dynamic phenomenon requires the provision of necessary conditions (Cheraghali, 2011). Therefore, it will be desirable to development an index, effective factors and obstacles for entrepreneurship in small businesses.

There is wide literature on small units providing different definitions on this concept worldwide. These definitions vary given the age, demographic, and cultural structures and level of development (Institute for Business Studies and Research, 2005). Since recognizing the importance of small businesses in the 1920s, no comprehensive and single definition has been provided (Talebi, 2007). During the Iran's civil planning period, only two factors have been considered as the base for defining the small businesses including the number of employees and the small size of capital, as determining criteria for recognizing the size of small manufacturing workshops and distinction from medium-sized and large industries.

Based on the definition provided by Ministry of Cooperatives of Industries and Mines of Jihad Agriculture, small and medium-sized enterprises are industrial and service units with fewer than 50 workers (Unidro, 2003). The Ministry of Cooperatives also uses the definitions of the Ministry of Industries and Mines and Iran's Statistics Center on these industries. The Iran's Statistics Center classified businesses into four categories: businesses with 1 to 9 workers, businesses with 10 to 49 workers, businesses with 50 to 99 workers, and businesses more than 100 workers (Iran's Statistics Center, 2005). In some countries, in order to define the small businesses, other indicators such as level of employees, volume of transactions and assets are used. However, according to the Iran's Jihad Agriculture Organization, the most important indicator for defining the size of small and medium-sized enterprises (SMEs) is the number of employees (Ministry of Jihad Agriculture of Iran, 2018).

There is lack of evidence in definitions provided regarding the philosophy of small industries reflecting the quality importance of small ones in the Iran's industrial development. However, specific definitions of small industry organizations vary from one organization to another and they are subject to different and sometimes contradictory rules and regulations when implementing a small nosiness unit (Sahraeian, 2001).

The Ministry of Agriculture Jihad considers the small agricultural businesses as agricultural activities in the fields of production, packaging and, in general, various agricultural activities, including livestock breeding, fish farming, etc., in which real and legal people, after completing steps and obtaining licenses, are allowed to carry out such activities within the limits specified by the organization itself. The license for establishment of Jihad agriculture is a prerequisite for obtaining a license for Agriculture Jihad exploitation. Some of these activities include the production and processing and protection of meat products, the processing and protection of the corruption of aquatic animals and aquatic products, the processing and protection of the corruption of fruits and vegetables, extracting the essential oils, dairy products, drying corn, powder of vegetables and fruits, processing rice, conversion industries related to various types of fruits, vegetables, tea and products derived from egg of birds and other animals, 
cleaning, grading and packaging of legumes, seeds and natural honey, production of prepared foods for animals without any concentrates and food supplements, fertilizers, different conversion industries of dates, types of plant essences and extracts (Ministry of Jihad Agriculture of Iran, 2018).

The entrepreneur and quick impact enterprises project in Iran with the aim of fair distribution of resources, increasing non-oil production and exports, and enhancing entrepreneurship, job creation and increasing new job opportunities was approved by Council of Ministers in the fall of 2005 and was implemented in the winter of the same year (Mostofi and Abbasi, 2010). Based on the report of the Islamic Consultative Assembly Research Center, this project and other similar ones have not been successful (Azhdari, 2012). Paying attention to creating more employments by establishing new enterprises rather than maintaining them, neglecting the withdrawal of enterprises from activity cycle has led to the loss of opportunities, so that studies show that most of the small businesses fail in the early years of their establishment (Feyzpour et al., 2011; Azar et al., 2012; Parsa Pour et al., 2012). Moreover, about 23\% of small units fail in the first year and almost $42 \%$ of them fail at the end of the fifth year due to various reasons (Vahdat and Dadashi, 2010).

Small quick impact enterprises in the agricultural sector are often called as entrepreneur units. These questions are always asked: whether small agricultural businesses are entrepreneurs? Would they face these problems if these businesses are entrepreneurs? What is the criterion of entrepreneurship in these businesses? How can they be evaluated? Is the goal of their establishment only to create employment for most of villagers? If goals other than job creation are expected from these types of businesses and what are these goals? What are the factors affecting the development of entrepreneurship in these businesses? Entrepreneur businesses can be identified when we use an appropriate index, so that we can evaluate them based on these indicators as well as developing their entrepreneurship as much as possible. For strategic planning to facilitate agricultural entrepreneurship, paying attention to explain the components of entrepreneurship and structures related to agricultural businesses, such as a complex system, underlying variables and related dynamics is essential (Sharifzadeh et al., 2009).

However, different studies proposed different factors for entrepreneurship of small businesses. Entrepreneurship personality characteristics, organizational characteristics, management strategies and the influence of external environment are affecting the creation of a successful business (Zaridis and Mousiolis, 2014). There is an agreement between entrepreneurship scholars about the role of individual differences in entrepreneurial process (Ardichvili and Cardozo, 2000; Davidsson and Honig, 2003; Arenius and Clercq, 2005). For example, risk-taking, innovation, independence, competitiveness, and being active include some affecting factors of small businesses performance (Hughes and Morgan, 2007). Based on some other studies, self-efficacy, creativity, commitment, willing to take risks and positive attitude are the main entrepreneurs` characteristics. They had the positive and significant effect on opportunity recognition in the various studies among different entrepreneurs (Kickul et al., 2009; Wang and Fang, 2012; Hansen et al., 2011; Gielnik et al., 2012). The reason seems to be that variables such as personality traits are the vital component of entrepreneurship, not just a specific sector. Only a few of small businesses have been able to achieve sustainable growth in terms of their performance. It should be considered that personality 
traits are not enough for success and business performance due to the studies (Sidik, 2012). Another factor which has effect on entrepreneurial process is also associated with entrepreneurs' interpretations about business environment (Tumasjan and Braun, 2012). The results of Wang and Fang (2012) showed that perception about the industrial environment is the most important predictor of taking risk to create entrepreneurial small businesses. Lee and Wong (2006) included that environmental factors are among the important determinants of entrepreneurial opportunity creation and development. It should be considered that various enterprises have different space, conditions, and environment. So, determining the environmental factors which are sector-specific would be a good guide for the newly founded enterprises. Considering the environmental factors are even more important in agricultural entrepreneurial enterprises due to the nature of agriculture. Agriculture sector encounter many risks and uncertainties making different condition. Therefore, entrepreneurial process would be affected under such conditions. Environmental uncertainty is a concept that seems to be appropriate for considering specific features of agriculture sector. Regarding to the findings of recent studies, the access of entrepreneurship enterprises to knowledge improves human, social, and organizational capitals (Simsek and Heavey, 2011). According to Arasti et al. (2014) and Izadi and Rezaei-Moghaddam (2017), inappropriate business environment and policies, poor management skills, inappropriate financing and pricing strategies are factors affecting failure of entrepreneurship enterprises. The results of Wiklund and Shepherd (2005) in Australia indicated that the entrepreneurship orientation of the company, access to capital and the dynamics of the business environment are effective in performance of small businesses.

Bidokhti and Zargar concluded that more than $95 \%$ of the total manufacturing units in Iran are small and medium-sized enterprises, but they do not have significant contribution in gross national production and creation of value added and suffer from severe deficiencies. The barriers and problems of these enterprises activities consist the lack of adequate knowledge of their needed assistance, lack of financial resources and problems in receiving bank facilities, low specialized workforce and inadequate knowledge and skills of existing workforce. Old machinery, high interest rates of facilities, vagueness of some business and commercial rules, an increase in intermediaries, the wide smuggle of goods to the country, the large number of current foreign competitors in the market, the welcome of consumers from foreign products, the traditional activities in the field of industry and the lack of economic, financial and management knowledge, especially at the establishment time have been reported as problems in this regard (Bidokhti and Zargar, 2011).

Sharifzadeh et al. (2009) described the development of agricultural businesses as a major strategy for promoting entrepreneurship in agriculture. They discuss that the major structures affecting the development of agricultural businesses are individual dimensions (motivation and economic, social, individual goals, and individual capabilities); business dimensions (production resources management, human resources development, communications and links, market management, business management and job functions in the business); skill learning in business area and supportive environment (institutional, family, and spiritual), business environment and infrastructure, economic, social and institutional macro environment. The results of a study conducted entitled "examining the extent of realization of the goals in quick impact 
enterprises project", showed that those who created business through this project did not have acceptable performance in profitability, job creation and production, and the objectives of this project have not been realized (Mostofi and Abbasi, 2010). Based on the results of Sharifzadeh et al. (2009) showed that many of the small and medium-sized enterprises created in different sectors do not have an adequate level of sustainability in the economic, social and environmental dimensions, and owing to facing various barriers and problems, their growth and survival have been questioned in many countries, including Iran. The study also emphasizes that the environmental, economic, and social values should be considered in the context of a community and system approach in order to have sustainable small businesses.

Studies conducted by Khodamipour and Shafiei (2013) showed that although a business in the agricultural area may benefit from its business activities in the short run, criteria such as the social behavior of the business, ethical accountability, and the consideration of other stakeholders' interests, ensure the survival of company (Khodamipour and Shafiei, 2013). In addition, the agricultural work experience of the managers of these businesses, the number of household members of manager, the amount of loans received to establish business, the manager's education, the manager's age, the number of workforce employed in the business, the distance from the business location to the city and the area under cultivation had a significant impact on the success of these businesses (Mollashahi et al., 2014).

Rezaei and Safa (2016b) realized that despite the importance of small and medium-sized enterprises, as one of the main tools to economic development, these enterprises especially in the agricultural sector of the country, have not been developed desirably and their success rate has been very low. They argue that the factors affecting the development and success of the activities of these types of businesses are the supportive policies, granting of facilities and credits, development of appropriate rules and removing administrative barriers, training the managers of enterprises, and the establishment of effective communication between enterprises.

This paper extends the entrepreneurship concepts by determining special index, effective factors and obstacles for development of entrepreneurship in small agricultural quick-impact enterprises. Small and Medium Enterprises (SMEs) has been raises in last two decades, worldwide. As development of SMEs has become the main economic policies of different countries (Yeh-Yun and Zhang, 2005). SMEs are defined as commercial-productive units which work at small scale (Rezaei and Safa, 2016a). These SMEs are formed based on the four indices of the number of enterprise personnel, whole net properties, sales level as well as enterprise investment (Amin Bidokhti and Zargar, 2012; Soltani et al., 2012). The 44th principle of Iran constitution made the route easier for the entrepreneurs' activities. These enterprises constitute less than 50 workers and work in agriculture, industry and mine sectors. They should achieve to the production phase in 12 to 14 months, therefore they have named as quick-impact enterprises (Alsadat Aghili et al., 2013). These enterprises would provide a place for the country development. Considering comprehensive definition of entrepreneurship, this study was conducted to identify the factors and obstacles to entrepreneurship development in quick-impact enterprises in Iran. Providing credible strategy as in order to develop the entrepreneurship process in small enterprises is the main aim of measuring the entrepreneurship components. The importance of index development as well as 
determining the factors and obstacles in entrepreneurship process are three main areas which have been emphasized in the studies: measuring entrepreneurship; improving the understanding of who is an entrepreneur (Tåg et al., 2016); determining ideal condition to undertake an entrepreneurial business; presenting a comprehensive definition; identifying potential entrepreneurs (Coduras et al., 2016); distinguishing between entrepreneurship and other modes of occupation (Crecente-Romero et al., 2016). Thus, developing entrepreneurship activities index in agricultural quick-impact enterprises answers the question that "what is the goal of entrepreneur businesses." It provides a framework for assessing and comparing the businesses with each other.

\section{Research method}

The study was conducted in two phases. Developing an entrepreneurship index in agricultural quick-impact enterprises was the main purpose of the first phase using Delphi method. Identifying factors affecting the developed index as well as determining the obstacles were the main objectives of the second phase of the study using survey research. There are three main objectives for this study: (a) development of an index for the entrepreneurship of SMEs, (b) determining the affecting factors of entrepreneurship process of SMEs, and (c) recognition of the barriers and obstacles encountered by the SMEs in their entrepreneurial process development.

\section{The first phase of the study}

To develop entrepreneurship activities index in quick-impact enterprises, Delphi method was conducted in the following steps:

A) First step, designing and analyzing team: Preparing questionnaires and analysis of the results, a team consisting of six experts of agricultural extension and education at Shiraz University and the specialists of Agriculture Jihad Organization of Fars Province was used.

B) Second step, Delphi group: It is a group of 34 experts of entrepreneurship in the agricultural sector of Fars province. The group consists of 12 professors who are specialist in entrepreneurship research in the school of Agriculture at Shiraz University, as well as 16 entrepreneurship specialists of Agricultural Jihad Organization of Fars Province, and 6 top managers of small businesses in this province.

C) Third step, semi-structured interviews with the Delphi group: Important concepts were defined in the first questionnaire. Then, we asked the Delphi group to define entrepreneurship development in small businesses of agricultural sector and give an explanation for each of the considered items and components so that classify the factors and reach a consensus. Data was organized, similar comments were combined and grouped responses were summarized as far as possible. Finally, conceptualization of entrepreneurship development items and components was conducted.

D) Fourth step, revision of responses: At this stage, components and items were included based on classification and sent to the members of Delphi group along with a copy of the responses in the questionnaire of previous stage. Then, they 
were asked to confirm or change their responses according to views and comments of other members of the Delphi group members and modify the presented classification of factors, if necessary.

E) Fifth step, designing and completing the third questionnaire: At this stage, respondents were asked to adjust the importance of each component and item in Likert scale due to the results of the previous round. Finally, rating was carried out due to extracted components and items to measure the development of entrepreneurship in small quick-impact enterprises. After rating, the importance mean of each component and item was calculated.

\section{Second phase of the study}

Determining the entrepreneurship development index of quick-impact enterprises, a survey was accomplished in this phase. Population of the study included small agricultural businesses operating in the form of quick-impact enterprises in rural areas of Fars province, Iran. Sample size of 151 business units was determined due to the Morgan table (Krejcie and Morgan, 1970) among these units in rural areas of the province. Data collection instrument was a questionnaire and views of professors in agricultural extension and education were used to assess the validity. Reliability of scales of questionnaire was determined through pilot study among 30 individuals outside of the main sample. Questionnaire was modified due to the pilot study. Cronbach's alpha coefficients for the sections of the questionnaire ranging from 0.64 to 0.91 , indicating that of questionnaire is desirable. To analysis of data, $\operatorname{SPSS}_{20}$ software and descriptive and inferential statistical techniques were used. Entrepreneurship development in quick-impact enterprises is the dependent variable and independent variables are outlined below:

The variable of management skills, including interpersonal skills and process skills were assessed by 8 items (Zaridis and Mousiolis, 2014) and self-managed training variable was assessed using 4 items (Tåg et al., 2016) with five choices Likert scale (strongly disagree to strongly agree). Government policies including supportive, advisory-educational and incentive policies were assessed with 12 items, and business environment, including components of ownership registration, licensing, export, employment, receiving facilities, support of investors, bankruptcy and dissolution was measured using 22 items (Coduras et al., 2016). The variable of knowledge management including the components of socialization, externalization, combination and internalization was measured with 8 items (Davidsson et al., 2001).

\section{Results and discussion}

\section{Developing entrepreneurship development index}

According to the previous stages, 11 components of entrepreneurship development for small businesses have been identified. This index would be useful for comparison of the current and past situation. The results of the first and the second stages presented in Table 1 and 2.

Delphi group regards job creating as one of the components of entrepreneurship development for small businesses. So that, they have noted the notion of job creating 87 times. By occupation it is meant that to be busy or engaged in a work in a manner that the person gains income. According to the results of Delphi group, this component has 
Table 1 Index of entrepreneurship development in agricultural small businesses

\begin{tabular}{|c|c|c|}
\hline Number & Concept (Component) & Worldviews of subjects \\
\hline 1 & Profitability & $\begin{array}{l}\text { Doing an economic activity (21), Creating efficiency in business (4), } \\
\text { Utility of business in indices like: the period of the return of capital } \\
\text { gain, net income, etc. (7), Improvement and increase in liquidity (3), } \\
\text { Revenue of business (28), Economic benefit (9) }\end{array}$ \\
\hline 2 & Creating job & $\begin{array}{l}\text { Occupation of employed and underemployed persons in village } \\
\text { (19), Decrease in unemployment pressure in the society (4), Creating } \\
\text { job (23), Creating balance in business (12), Creating hope and } \\
\text { happiness in the family (7), Eliminating financial need (19), } \\
\text { Promoting business in the society (3) }\end{array}$ \\
\hline 3 & Innovation & $\begin{array}{l}\text { Variety in product or service (23), Creating new job (17), Innovative } \\
\text { use of technology (17), Doing an innovative activity in the area (8), } \\
\text { Information technology use for being up to date (2), Innovation use } \\
\text { to success in business (5) }\end{array}$ \\
\hline 4 & Stability of business & $\begin{array}{l}\text { Job stabilization (24), Traversing from the cycle of business and } \\
\text { arriving to development (19), Creating a stable job and preventing } \\
\text { from social damages (4), Stability in business (1), Failure to create a } \\
\text { cross-sectional and transitory business (12) }\end{array}$ \\
\hline 5 & Flexibility & $\begin{array}{l}\text { Gaining the ability of confronting with economic conditions (18), } \\
\text { Producing proper product according to market conditions (9), On } \\
\text { time reaction to the market changes ( } 7 \text { ) }\end{array}$ \\
\hline 6 & Customers' satisfaction & $\begin{array}{l}\text { Gaining a good sale market (15) Lack of problem for sale or delivery } \\
\text { of product (10), Gaining the assurance of producer from market } \\
\text { after the production (12), Purchaser's interests (4) }\end{array}$ \\
\hline 7 & Employees' satisfaction & $\begin{array}{l}\text { Retention and not firing of employees (14), Employees' utility from } \\
\text { the advantages of work (6) }\end{array}$ \\
\hline 8 & $\begin{array}{l}\text { Regional welfare and } \\
\text { development }\end{array}$ & $\begin{array}{l}\text { Removing employees' concern of economic problems (10), } \\
\text { Providing conditions improving the future of human beings in } \\
\text { terms of physical, spiritual, work and study (5), Eliminating } \\
\text { discrimination in the society (11), Being effective in the area } \\
\text { development (8), Rapid coordination of local resources (10), } \\
\text { Using seasonal and local workforce (15) }\end{array}$ \\
\hline 9 & $\begin{array}{l}\text { Challenging and taking } \\
\text { advantage of opportunities }\end{array}$ & $\begin{array}{l}\text { Creating business or increasing the amount of branches in a } \\
\text { targeted and justified manner (16), Capability of competition with } \\
\text { larger businesses (11), Attracting customers by offering a better } \\
\text { product and a better quality (5), Welcoming new ideas, identifying } \\
\text { and analyzing opportunities (4), Maintaining people's power for the } \\
\text { product selection (19), Analysis of current situation (4) }\end{array}$ \\
\hline 10 & Protecting environment & $\begin{array}{l}\text { Using the safe technology (9), Observing health requirements (8), } \\
\text { Creating a green job (11), Producing a healthy product (7), Reducing } \\
\text { pollution and energy consumption (12) }\end{array}$ \\
\hline 11 & Ideas commercializing & $\begin{array}{l}\text { Selecting a brand or commercial name (6), Using technology for } \\
\text { creating value (6), Success in implementing the idea (10) }\end{array}$ \\
\hline
\end{tabular}

Note: The numbers in parentheses represent the frequency of repetition of concept from the subjects' worldviews

been the most important concept. The group said that a business should be money making and be appropriate in terms of some factors such as payback period and net income. Generally, business is expected to be regarded as an economic activity and associate with increase in liquidity. These memos represent the concept of profitability of a business which is mentioned by the Delphi group for 72 times. Ahmadpur Dariani and Azizi (2004) believe that the most important purpose of the business is gaining profit for retaining cash and revival. Innovation is another component that the Delphi group have noted about 72 times. They have expressed that variety or a new job should be provided for the product and business services and a creative use of technology should be applied. Due to the perspective of eight members of the Delphi group, entrepreneurship development would be possible when an innovative activity implements in the area and technology should be applied for being up to date. 
Table 2 Mean of the components of entrepreneurship development index according to Delphi

\begin{tabular}{ll} 
group & Mean \\
\hline Components & 15.31 \\
\hline Innovation in product or service & 14.27 \\
Profitability in production & 12.50 \\
Protection of environment & 14.95 \\
Competitiveness & 14 \\
Regional welfare and development & 14 \\
Ability to adapt & 14.27 \\
Creating job & 13 \\
Customer satisfaction & 13.5 \\
Employee satisfaction & 15.70 \\
Commercializing the idea & 14.22
\end{tabular}

Entrepreneurship Development Index components range: 3 to 20

Another concept which is gained from the interviewees' memos is the component of stability in business. The Delphi group have noted 60 times that a business is expected to be stable and retains the cycle of business. So stability in business means increase in efficiency, stabilization of job, traversing business cycle without compromising new generations for meeting their own needs. The other concept which is gained from the Delphi group's explanations is flexibility in business. In other words, they believe that a business should be able to accommodate its product with the market and environment in the crisis of market conditions or environmental conditions in order to be successful. The interviewees have noted to such sentences 34 times. So what makes business to be protected from unreliable conditions of environment with rapid changes, is called flexibility. The Delphi group believed that the employers should be insured and not fired. Also 15 experts of the Delphi group have noted to the importance of the sale market and it is repeated for 12 times that when the producer is sure that after production his product would not be confronted with the problems of sale in the market. In that case, it can be said that it has reached to the business development. These memos present retention of employees and customers' satisfaction.

Regional welfare and development is another notion which is expressed by the Delphi group. They believe that these businesses should provide the participation of the private sector and eliminate discrimination in the society. It is repeated 15 times that small agricultural businesses in the village should be able to recruit the natives and create job for the young people in the area. It is stated for 10 times that buying raw material from the business which are existed in the area could improve the economy of that area as much as possible. The village environment has lots of potentialities for providing raw materials of agricultural small businesses. In some cases, the government applies the tools of creating small businesses and entrepreneurship development in order to create a socio-economic zone (especially in deprived areas) and eliminating discrimination among the members of the society, occupation of natives, and utilizing from the raw materials which are produced in the area. Other concepts which are extracted from the memos of Delphi group include starting business objectively, justification before starting the activity, identification and knowledge of the sale market, increase in the amount of the branches, and variety in the produced product. These statements present the 
concept of challenging and opportunities use which are repeated 59 times. Challenging means the firms ability in a competition condition.

One of the concepts which is rarely noted in the researches as entrepreneurship development index in small businesses is environmental conservation. The memos of producing a healthy product, reducing the pollution and energy consumption, observing health requirements, creating a green job using safe eco-friendly technology are stated for 47 times by the experts group. They believe that the objectives of small businesses and especially home works are producing healthy food, reducing pollution and energy consumption. Ideas commercializing is another component which is noted by the expert group less than the other factors. It might be because this concept was not very tangible. Other statements of the interviewees are relating to the use of a brand and technology for creating value and success in implementing the idea which is repeated more than 22 times. Commercializing the idea means that a concept or idea becomes an opportunity. In other words, the process of introducing a product or service to the market is called commercializing the idea.

In the last stage, investigating the extracted index from the statements of the Delphi group, the importance degree of the components in the small businesses is measured by a questionnaire due to the results of expert group interviews. According to the results presented in Table 2, all the components of the proposed index has a high average.

\section{Analysis of entrepreneurship development index}

Table 3 shows that how successful the business owners of quick-impact enterprises were in implementation of entrepreneurship development items of components in the first year of inauguration of the business and the current year. In the first year, the item of using local manpower had the highest rank, meaning that in the beginning of the establishment of enterprise, the criterion of being local in employment is considered. The second rank belongs to item of maintaining the business cycle. In the beginning of their activity, owners of quick-impact enterprises are looking for production, sales and profits in order to reproduce, which collectively form the business cycle (rank 2). Keeping the business cycle in the first year, owners of enterprises tried to consider optimal price for productions (rank 3). They analyzed and assessed the needs of customers (rank 5) and they gave higher importance to reduce energy consumption more than other items (rank 4). In the first year, the sixth priority was to invest in the business and after the maintaining of the business cycle, studied enterprises bought equipment to invest in business (rank 6). They aimed to sustainable business (rank 7). Reducing pollution as one item of environmental protection component was ranked eight. In the first year, business owners used local raw materials in their business so that their production meets the needs of the region in a way that these items ranked nine and ten. Eleven and twenty ranks belonged to sales rate and competition with other rival businesses. In these businesses, the business production rate ranked 13. These businesses could represent quite timely response to profitable transactions compared to other items. This item ranked 15. Creating job of enterprise and make decision to creating job in future years ranked 16 and 17, respectively. In the studied enterprises, retention of staff, providing equipment or facilities to compete with other competitors, providing power to compete with other competing businesses, export, the ability to change 
Table 3 Rank mean of entrepreneurship development items in small agricultural quick-impact

\begin{tabular}{|c|c|c|c|c|}
\hline $\begin{array}{l}\text { Rank in the } \\
\text { current year }\end{array}$ & $\begin{array}{l}\text { Mean in the } \\
\text { current year }\end{array}$ & Items of entrepreneurship development & $\begin{array}{l}\text { Mean in the } \\
\text { first year }\end{array}$ & $\begin{array}{l}\text { Rank in the } \\
\text { first year }\end{array}$ \\
\hline 28 & 2.75 & Production of new product or service & 2.21 & 28 \\
\hline 17 & 3 & $\begin{array}{l}\text { Use of new production methods or new } \\
\text { techniques }\end{array}$ & 2.07 & 29 \\
\hline 20 & 2.92 & The use of new resources or raw materials & 2.25 & 26 \\
\hline 7 & 3.45 & Reduced pollution & 2.97 & 8 \\
\hline 1 & 3.67 & $\begin{array}{l}\text { Giving importance to reduced energy } \\
\text { consumption }\end{array}$ & 3.06 & 4 \\
\hline 8 & 3.43 & Needs assessment of customers & 3.04 & 5 \\
\hline 13 & 3.20 & Considering optimal price for product & 3.09 & 3 \\
\hline 18.5 & 2.93 & Insurance of staff & 2.29 & 25 \\
\hline 18.5 & 2.93 & Retention of staff & 2.64 & 18 \\
\hline 30 & 2.27 & $\begin{array}{l}\text { Considering fellowship and marriage cost to } \\
\text { the staff }\end{array}$ & 2.04 & 30 \\
\hline 23.5 & 2.89 & $\begin{array}{l}\text { The ability to change according to changing } \\
\text { market conditions }\end{array}$ & 2.46 & 22 \\
\hline 29 & 2.73 & $\begin{array}{l}\text { Change the product due to environmental } \\
\text { conditions }\end{array}$ & 3.36 & 24 \\
\hline 10 & 3.31 & Equip their facilities to compete with rivals & 2.61 & 19 \\
\hline 16 & 3.01 & Meet the needs of society through product & 2.90 & 10 \\
\hline 14 & 3.08 & Use of local raw materials (if any in this region) & 2.91 & 9 \\
\hline 9 & 3.33 & The use of local manpower & 3.32 & 1 \\
\hline 25 & 2.88 & The employment rate of small business & 2.67 & 16 \\
\hline 22 & 2.90 & The share of employment in the next year & 2.66 & 17 \\
\hline 5 & 3.49 & Production rate & 2.78 & 13.5 \\
\hline 6 & 3.46 & Sales rate & 2.84 & 11 \\
\hline 21 & 2.91 & Exporting of product & 1.56 & 21 \\
\hline 12 & 3.22 & investment to equip business & 3.01 & 6 \\
\hline 4 & 3.52 & Business stabilization & 3.11 & 7 \\
\hline 3 & 3.53 & Maintain business cycle & 2.97 & 2 \\
\hline 23.5 & 2.89 & $\begin{array}{l}\text { Providing power to select the product through } \\
\text { variety of product for customers }\end{array}$ & 2.59 & 20 \\
\hline 11 & 3.29 & Competition with other rival businesses & 2.79 & 12 \\
\hline 2 & 3.66 & Timely response to profitable deals & 2.77 & 15 \\
\hline 26 & 2.81 & Choose a brand for the production unit & 2.42 & 23 \\
\hline 15 & 3.04 & Success in implementing the ideas & 2.78 & 13.5 \\
\hline 27 & 2.76 & Using technology to create value and wealth & 2.22 & 27 \\
\hline
\end{tabular}

according to market conditions and environmental conditions, selection of brand, staff insurance, use of sources or new raw materials, production or new services, use of new production methods or new techniques, and finally considering the various allowances to staff ranked 18 to 30 , respectively.

In the current year, giving importance to reduced energy consumption had the highest rank in the studied enterprises. Environment protection had higher rank in comparison with the first year of business inauguration. It was probably due to increased costs of the energy that was before cheaper. In the current year, after exhibiting timely 
responses against profitable transaction (rank 2), quick-impact enterprises tried to maintain the business cycle (rank 3) and consolidation and sustainability of business (rank 4). They have increased production and sales rate in the current year (promotion in rank 13 to 5 and from 11 to 6). Needs assessment of the customers had lower rank than the first year. The use of local manpower as one item of regional development indicators has dropped to rank 9 in the current year, meaning that in the current year less attention is given to recruit local manpower, but high importance is given to providing facilities to compete with other rivals. Giving importance to optimal price for product dropped from rank 3 to rank 13, and use of local raw materials dropped from rank 9 to 14. Satisfying needs of society, using new production methods or new techniques, use of new resources or raw materials, staff insurance, retaining staff, exports, employment, and power of selection of product through variety for customers, placed in next and the last rank.

Paired t-test results indicated that there are significant differences between the mean of entrepreneurship development components with the exception of regional welfare development in the first year of business establishment and the current year (Table 4). The range of components is 3 to 20 . The score mean of creation of innovation component was 6.53 and 8.68 in the first year of working and the current year, respectively which was an improvement in this component. There is also a significant difference between the protection of the environment in the first year and the current year. The mean of customer satisfaction increased from 9.19 to 9.94 that has significantly difference between the two time periods of the study at the level of 0.002. It is a significant difference between the ability of adapting to market conditions in the two years at the 0.0001 level. Mean of employment increased significantly from 7.99 in the first year of establishment to 8.68 in the current year. There is also significant difference between commercialization of the idea in the two time points of the study at the 0.01 level. The results of paired t-test indicate that there is significant difference between the entrepreneurship development of businesses in the first year and current year. In other words,

Table 4 Results of paired T-test comparing the mean of components of entrepreneurship development index in quick-impact enterprises in the first year of working and the current year

\begin{tabular}{|c|c|c|c|c|c|c|}
\hline \multirow[t]{2}{*}{ Variable } & \multicolumn{2}{|c|}{ First year } & \multicolumn{2}{|c|}{ Current year } & \multirow[t]{2}{*}{ t } & \multirow[t]{2}{*}{ sig } \\
\hline & mean & SD & mean & SD & & \\
\hline Innovation in product or service & 6.53 & 2.54 & 8.68 & 2.97 & -8.21 & 0.0001 \\
\hline Environment protection & 9.04 & 3.38 & 10.68 & 2.92 & -6.88 & 0.0001 \\
\hline Customer satisfaction & 9.19 & 3.25 & 9.94 & 3.58 & -3.72 & 0.002 \\
\hline Staff satisfaction & 6.97 & 3.31 & 8.13 & 3.43 & -6.50 & 0.0001 \\
\hline Adaptation ability & 7.43 & 2.51 & 8.93 & 3.26 & -6.38 & 0.0001 \\
\hline Regional welfare and development & 9.13 & 2.45 & 9.42 & 2.94 & -1.14 & 0.2 \\
\hline Employment & 7.99 & 3.07 & 8.68 & 3.71 & -2.34 & 0.02 \\
\hline Profitability & 7.64 & 2.28 & 9.81 & 2.28 & -7.32 & 0.001 \\
\hline Competitiveness & 9.12 & 2.39 & 10.57 & 4.53 & -4.87 & 0.0001 \\
\hline Business sustainability & 8.15 & 4.24 & 9.84 & 3.81 & -4.51 & 0.0001 \\
\hline Commercialization of ideas & 7.42 & 2.56 & 8.61 & 3.92 & -6.75 & 0.01 \\
\hline Sum of components & 7.04 & 1.56 & 8.89 & 2.10 & -12.19 & 0.001 \\
\hline
\end{tabular}

Range of each of components: $3-20$ 
entrepreneurship development index in the studied businesses is moderate and it improved relatively compared with first year.

\section{Factors affecting entrepreneurship development of quick-impact enterprises}

Stepwise regression was used to provide the collective impact of independent variables on entrepreneurship development quick-impact enterprises (Table 5). According to this table, $F$ value is significant at the level of 0.0001 . In general, the variables included in the regression analysis explain $58 \%$ of the variance of entrepreneurship development in these businesses. The first factor affecting business entrepreneurship development in quick-impact enterprises is management skills in business. Variable of use of management knowledge predicts $12 \%$ of entrepreneurship development. Indeed, as the owner of enterprise makes his business knowledge-oriented, entrepreneurship development will be at a higher level. Edvardsson and Durst (2013) and Izadi and Rezaei-Moghaddam (2017) also focused on the advantages of knowledge management in small businesses. Business environment, as third influential variable, has positive impact on the entrepreneurship development in the enterprise. The results of Saleh and Ndubisi (2006) and Izadi et al. (2016) confirmed the importance of the business environment in small businesses. The fourth influential variable is self-managed trainings by owners of these businesses. Business owners who seek to learn through self-managed trainings have more developed businesses in terms of entrepreneurship. Government support policies, such as improving the conditions for the sale of products, availability of raw materials, approving appropriate rules and laws, and providing underlying conditions, are considered as other factors affecting the entrepreneurship development in quick-impact enterprises. In other words, as government supports business highly, it can be expected that the entrepreneurship development will be higher. The results of Tambunan (2008) also confirmed the role of government policies in small businesses. Based on multiple regression analysis, the following equation can be used to estimate the entrepreneurship development of quick-impact enterprises:

$$
\mathrm{Y}=0.39_{x 1}+0.26_{x 2}+0.35_{x 3}+0.24_{x 4}+0.17_{x 5}
$$

Where $\mathrm{Y}$ is entrepreneurship development level in quick-impact enterprises, $\mathrm{x}_{1}$ is management skills, $x_{2}$ is use of knowledge management, $x_{3}$ is business environment, $x_{4}$ is self-managed training, and $x_{5}$ is government policies.

As beta values showed the variables including management skills, business environment, use of knowledge management, and self-managed training and government supportive policies had the highest share in the changes of dependent variable, respectively. Regression analysis showed that per one unit change in the standard deviation of management skills, 0.39 of

Table 5 Results of regression analysis on the variables affecting the entrepreneurship development of quick-impact enterprises

\begin{tabular}{lllllll}
\hline Variables & $\mathrm{B}$ & $\mathrm{Beta}$ & $\mathrm{t}$ & $\mathrm{R}$ & $\mathrm{R}^{2}$ & $\mathrm{R}^{2} \mathrm{Ad}$ \\
\hline Management skills & 2.62 & 0.39 & 5.14 & 0.34 & 0.12 & 0.11 \\
Using knowledge management & 0.98 & 0.26 & 2.71 & 0.50 & 0.25 & 0.23 \\
Business environment & 2.15 & 0.35 & 7.04 & 0.58 & 0.47 & 0.46 \\
Self-managed training & 0.42 & 0.24 & 3.58 & 0.62 & 0.56 & 0.55 \\
Government policies & 1.2 & 0.17 & 3.11 & 0.65 & 0.60 & 0.58 \\
\hline
\end{tabular}

$\mathrm{F}=91.12 \mathrm{Sig}=0.0001$ Constant $=27.71$ 
change is created in standard deviation of entrepreneurship development in the enterprise. The results of study by Lerner et al. (1997) and Izadi et al. (2016) also confirmed the impact of management skills on performance of small businesses. In addition, per one unit of change in the standard deviation of business environment, 0.35 value of change is created in the standard deviation of development of entrepreneurship in the enterprise, and per one unit of change in standard deviation of use of knowledge management, 0.26 value of change is created in standard deviation of entrepreneurship development. According to the results in Table 5 , for each unit of change in standard deviation of self-managed training, 0.24 value of change is created in standard deviation of entrepreneurship development, and each unit of change in standard deviation of government policies creates 0.17 value of change in the standard deviation of the dependent variable in this type of business. Results of Kamunge et al. (2014), Izadi and Rezaei-Moghaddam (2017) and Izadi et al. (2016) also confirmed the importance of management skills, government policies and business environment in small businesses.

\section{Obstacles in entrepreneurship development of quick-impact enterprises}

For internal consistency of some items related to the problems and obstacles in business of quick-impact enterprises and limiting the items affecting to a number of factors, factor analysis was used. The number of factors depends to eigenvalue. In this analysis, the value of KMO was obtained 0.75. Bartlett test value was also significant at the level of 0.01. According to the total number of variables included within each factor, five obstacles of agricultural quick-impact enterprises were identified. According to Table 6, the percentage of the variance of each factor has been specified. All of the five factors had $68.83 \%$ of the whole variance. In addition, the factor loading of variables of each factor was calculated in which we can identify high value and more important variables, and eliminate variables that factor loading of lower than 0.50 .

Based on Table 6, five major obstacles and problems were determined for the small agricultural quick-impact enterprises due to the sum of the items. The first factor can be called as financial problems include strict rules to get loans, repayment interest of loans, failure to get timely loans and lack of ability in providing raw materials. This finding is consistent with results of Olawale and Garwe (2010). The second factor includes items related to the sales market. Therefore, these items were labeled as market obstacles. Entrepreneurs occupy a central position in a market economy. The economic success of nations worldwide is the result of encouraging and rewarding the entrepreneurial instinct. The third factor defines the items in terms of information weakness of complementary and specialized business, plan implementation, investment information, and supportive projects as well as lack of familiarity to entrepreneurship knowledge. The fourth factor named as legal factor or inappropriate business environment includes items that indicate poor government planning and regulation and administrative bureaucracies. The findings are consistent with results of Sherazi et al. (2013). The fifth factor includes items of drought and reduced physical strength indicating insecurity and lack of insurance business and weakness in the supportive policies of government.

\section{Conclusion}

Entrepreneurship development is an evolving process. It requires entrepreneurs taking advantage of the opportunities and is affected by various components. This requires the 
Table 6 Results of factor analysis to determine the obstacles of entrepreneurship development of quick-impact enterprises

\begin{tabular}{|c|c|c|c|c|c|}
\hline Factors & $\begin{array}{l}\text { Name of } \\
\text { factor }\end{array}$ & Items & $\begin{array}{l}\text { Factor } \\
\text { loading }\end{array}$ & $\begin{array}{l}\text { The percentage } \\
\text { of explained } \\
\text { variance }\end{array}$ & $\begin{array}{l}\text { The percentage } \\
\text { of accumulative } \\
\text { variance }\end{array}$ \\
\hline \multirow[t]{4}{*}{1} & \multirow{4}{*}{$\begin{array}{l}\text { Financial } \\
\text { obstacles }\end{array}$} & Strict rules to get loans & 0.89 & \multirow[t]{4}{*}{16.8} & \multirow[t]{4}{*}{16.88} \\
\hline & & Repayment interest of loans & 0.87 & & \\
\hline & & Lack of ability to get timely loans & 0.88 & & \\
\hline & & Inability to obtain raw materials & 0.63 & & \\
\hline \multirow[t]{3}{*}{2} & \multirow{3}{*}{$\begin{array}{l}\text { Market } \\
\text { obstacles }\end{array}$} & Significant changes in input prices & 0.81 & \multirow[t]{3}{*}{14.89} & \multirow[t]{3}{*}{31.78} \\
\hline & & $\begin{array}{l}\text { The uncertainty of the market situation } \\
\text { of the product }\end{array}$ & 0.69 & & \\
\hline & & Marketing problems & 0.85 & & \\
\hline \multirow[t]{3}{*}{3} & \multirow[t]{3}{*}{$\begin{array}{l}\text { Information } \\
\text { obstacles }\end{array}$} & $\begin{array}{l}\text { Complementary and specialized information } \\
\text { and expertise regarding the implementation } \\
\text { of plan }\end{array}$ & 0.86 & \multirow[t]{3}{*}{13.66} & \multirow[t]{3}{*}{45.45} \\
\hline & & $\begin{array}{l}\text { Obtaining investment and supportive plans } \\
\text { information }\end{array}$ & 0.79 & & \\
\hline & & $\begin{array}{l}\text { Lack of familiarity of business owner } \\
\text { with applied principles of entrepreneurship }\end{array}$ & 0.60 & & \\
\hline \multirow[t]{2}{*}{4} & \multirow[t]{2}{*}{$\begin{array}{l}\text { Legal } \\
\text { obstacles }\end{array}$} & $\begin{array}{l}\text { Interference and passing laws without } \\
\text { consulting with business owners }\end{array}$ & 0.79 & \multirow[t]{2}{*}{10.32} & \multirow[t]{2}{*}{55.78} \\
\hline & & $\begin{array}{l}\text { Bureaucracy or administrative bureaucracy } \\
\text { (high obstacles to get licensure and } \\
\text { registration of company) }\end{array}$ & 0.63 & & \\
\hline \multirow[t]{2}{*}{5} & \multirow[t]{2}{*}{$\begin{array}{l}\text { Supportive } \\
\text { obstacles }\end{array}$} & $\begin{array}{l}\text { Lack of insurance supporter } \\
\text { Shortage and outwear physical facilities }\end{array}$ & $\begin{array}{l}0.71 \\
0.50\end{array}$ & \multirow[t]{2}{*}{7.12} & \multirow[t]{2}{*}{68.83} \\
\hline & & Strict rules to get loans & 0.89 & & \\
\hline
\end{tabular}

structure and following the planed supportive functions and providing appropriate areas. Entrepreneurship development in quick-impact enterprises is a process seeking for profitability, employment, innovation, adaptability, flexibility, customer and staff satisfaction, regional welfare development, challenging opportunities, environmental protection, the commercialization of ideas and localization to develop the region. According to the results, the effective factors in the quick-impact enterprises include management skills, knowledge management use, business environment, self-managed trainings, and policies of government. As shown in Fig. 1, regarding entrepreneurship process, the components of entrepreneurship development located in the center of the model is affected by three elements of individual, environment, and enterprise-related factors which have shown in different sides of rectangle. This model suggests that entrepreneurship development should be viewed as a process that it is not achieved merely by individual entrepreneur, or facilities and supportive mechanisms or current conditions in the business. It should be noted that none of these three factors leads into entrepreneurship development separately. Indeed, entrepreneurship process would be occurred when one innovative and creative person dependent on himself identifies and uses the opportunities that government has provided, create a business with his management skills that its internal environment is in line with entrepreneurship process and take advantage of incentive, educational, and supportive polices during these processes. Therefore, it is recommended all three factors of entrepreneur, environmental factors, and internal factors of enterprises to be involved in determination and creation 


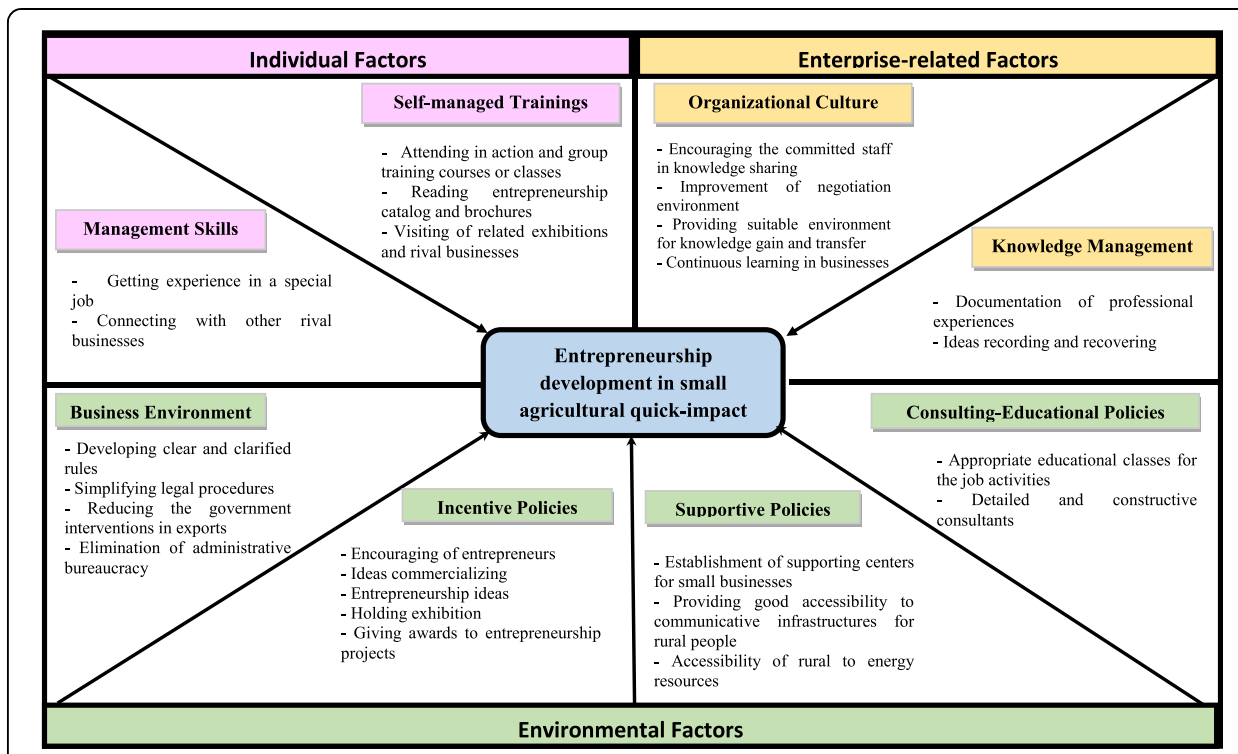

Fig. 1 Entrepreneurship development process in small agricultural quick-impact enterprises

of appropriate conditions of entrepreneurship development. It is reminded to authorities of entrepreneurship development that the criterion of evaluation should not be merely employment. A business that fails to maintain business cycle and cannot meet the customer and staff needs, it cannot create job or maintain the job opportunity, and it will be eliminated from market competition. Entrepreneurship should not be viewed only through an economic aspect, but also social aspect and even environmental components should be considered. It is therefore essential short-term and long-term goals should be consistent with entrepreneurship development index.

Iran's quick-impact enterprises are based on local manpower strategy to maintain business cycle in initial years of their activity. In fact, these types of businesses after production cycle and sales and profitability in early years, move toward customer satisfaction and protecting the environment and improving other components. In these businesses, the commercialization of ideas and innovations had the lowest rank. According to these cases, capital is seen as a very important in order to keep the business cycle and the improving other components, especially at the beginning of enterprises. Therefore, obtaining loans and financing are suggested to be in the priority, followed by commercialization of ideas and innovation. The impact of knowledge management and management skills on entrepreneurship development confirms that development of entrepreneurship in quick-impact enterprises is based on management and using of knowledge. In other words, these enterprises are knowledge-based. According to the analysis, knowledge management explains part of the changes in business entrepreneurship development quick-impact enterprises. So small agricultural businesses should be leading in obtaining correct information in various fields and they should seize the information more quickly and effective than their rivals so that they can provide a base for development of entrepreneurship sustainable competitive advantage. Information technology should have been used as a tool of information distribution by the businesses. These tools enable managers to transfer data into information and then into knowledge, and start to planning and budgeting based on scientific principles. 
Encouraging staff who have great role in knowledge development is highly recommended in order to share implicit and internal knowledge of the staff. It is proposed that negotiation atmosphere would be shaped informal chats in the form of discussions and debate since it paves for acquisition and transfer of knowledge. Creating a culture of continuous learning in the business improves capabilities and abilities in the business, and it can lead into obtaining information and knowledge in various fields of business such as market conditions, the purchase and advertising.

\section{Implications and future scope}

Based on findings, the government would be able to enhance and strengthen the implementation of educational-consulting policies by holding formal and informal training sessions such as seminars and panels, establishment of various centers in line with consulting of entrepreneurship businesses and forming entrepreneurship sites. Broadcasting related programs in public media, giving annual awards to rural entrepreneurs' businesses and entrepreneurship projects, adopting special terms and privileges for organizations supporting of rural entrepreneurship development projects, holding exhibitions and creating the conditions for small businesses, and holding agricultural small businesses achievement exhibitions are some suggestions to encourage entrepreneurs as well as their knowledge improvement. It is recommended that government establish the chain centers supporting of small businesses in rural areas, such as Entrepreneur Bank, Fund for Support of Small Businesses. Improving the business environment, it is recommended that clear rules to be developed to monitor issues such as licensing and receiving facilities, simplifying procedures, reducing the time and costs of the implementation of the components of the business environment, especially the efficiency of the judicial system and reduced government intervention in export and elimination of administrative bureaucracies. There are some suggestions for the future studies regarding entrepreneurship development of the SMEs:

- Assessment and monitoring of entrepreneurship activities in order to prepare for facing its consequences;

- Evaluation of entrepreneurship activities based on the developed index of this paper as well as other comparative studies in the other provinces of the country;

- Development of the index for evaluating of entrepreneurship activities in other enterprises.

Acknowledgements

We are thankful for the agricultural extension experts and the rural entrepreneurs of Fars province for answering the questionnaires, patiently.

Funding

The article has been extracted from a mater thesis and a kind of student work. There is no special fund to this research.

Availability of data and materials

The datasets generated and/or analyzed during the current study are not publicly available due [Because all of the data was gathered by the research team] but are available from the corresponding author on reasonable request. 


\section{Competing interests}

Providing an applicable index for defining entrepreneurship in small agricultural quick-impact enterprises focusing in rural areas and the rural women.

\section{Publisher's Note}

Springer Nature remains neutral with regard to jurisdictional claims in published maps and institutional affiliations.

Received: 30 July 2018 Accepted: 3 December 2018

Published online: 22 January 2019

\section{References}

Ahmad, N., \& Hoffmann, A. N. (2008). A framework for addressing and measuring entrepreneurship. OECD Statistics Working Paper, 2, 2-36.

Ahmadpur Dariani, M., \& Azizi, M. (2004). Entrepreneurship, office of planning and compilation of technical and professional trainings. Tehran: Mehrabe Ghalam Publication.

Alsadat Aghili, F., Tayebi, K., Zamani, Z., \& Ebrahimi, N. (2013). Effect of entrepreneurship and small and medium enterprises on employment: Evidences from developing countries. J Entrepreneur Dev, 5(2), 145-164.

Amin Bidokhti, A., \& Zargar, M. (2012). Pathology of small and medium enterprises and expression of practical strategies to support them (case study: Semnan Province). J Manag Dev, 78, 156-125.

Arasti, Z., Zandi, F., \& Bahmani, N. (2014). Business failure factors in Iranian SMEs: Do successful and unsuccessful entrepreneurs have different viewpoints? J Global Entrepreneur Res, 4(10), 1-14.

Ardichvili, A., \& Cardozo, R. N. (2000). A model of the entrepreneurial opportunity recognition process. J Enterprising Culture, $8(02), 103-119$.

Arenius, P., \& Clercq, D. D. (2005). A network-based approach on opportunity recognition. Small Business Economics, 24(3), 249-265.

Azar, A., Sadeghi, A., \& Nanaeic, A. (2012). Prioritizing the factors affecting the success of small and medium sized businesses in the field of superior technology: Fuzzy network analysis process approach. Entrepreneur Dev, 5(2), 165-180.

Azhdari, A. A. (2012). Evaluating and analyzing the performance of the executive order development of early-stage and entrepreneurial businesses. Islamic Consultative Research Center; Office of Energy Studies, Industry and Mines, Serial No. 12678.

Bidokhti, A. A., \& Zargar, M. (2011). Examining the barriers to the development of small and medium enterprises and providing a framework for supporting these firms, 138, 34-48.

Bird, B. (1988). Implementing entrepreneurial ideas: The case for intention. Academy of Management, 13(3), 442-453.

Carland, J. W., Hoy, F., Boulton, W. R., \& Carland, A. C. (1984). Differentiating entrepreneurs from small business owners: A conceptualization. Academy of Management Journal, 9(2), 354-359.

Chakraborty, S., Thompson, J. C., \& Yehoue, E. B. (2016). The culture of entrepreneurship. Journal of Economic Theory, 163, $288-317$.

Cheng, S., Stough, R. R., \& Jackson, R. W. (2009). Measuring and building high-quality entrepreneurship: A research prospectus. Inn Eur J Social Sci Res, 22(3), 329-340.

Cheraghali, A.R. (2011). Factors affecting the development of entrepreneurship in agricultural cooperatives. Master's thesis, Entrepreneurship Department, Tehran University, Tehran.

Coduras, A., Saiz-Alvarez, J. M., \& Ruiz, J. (2016). Measuring readiness for entrepreneurship: An information tool proposal. J Inn Knowledge, 1(2), 99-108.

Crecente-Romero, F., Giménez-Baldazo, M., \& Rivera-Galicia, L. F. (2016). Subjective perception of entrepreneurship. Differences among countries., J Business Res. https://doi.org/10.1016/j.jbusres.2016.04.097.

Davidsson, P., \& Honig, B. (2003). The role of social and human capital among nascent entrepreneurs. Journal of Business Venturing, 18(3), 301-331.

Davidsson, P., Low, M., \& Wright, M. (2001). Editors' introduction: Low and Macmillan ten years on-achievements and future directions for entrepreneurship research. Entrepreneurship Theory and Practice, 25(4), 5-16.

Edvardsson, I. R., \& Durst, S. (2013). The benefits of knowledge management in small and medium-sized enterprises. ProcediaSocial and Behavioral Sciences, 81, 351-354.

Gartner, W. B., \& Shane, S. A. (1995). Measuring entrepreneurship over time. Journal of Business Venturing, 10, $283-301$.

Gielnik, M. M., Frese, M., Graf, J. M., \& Kampschulte, A. (2012). Creativity in the opportunity identification process and the moderating effect of diversity of information. Journal of Business Venturing, 27(5), 559-576.

Hansen, D. J., Lumpkin, G. T., \& Hills, G. E. (2011). A multidimensional examination of a creativity-based opportunity recognition model. Int J Entrepreneur Behav Res, 17(5), 515-533.

Hayton, J., Chandler, G. N., \& DeTienne, D. R. (2011). Entrepreneurial opportunity identification and new firm development processes: A comparison of family and non-family new ventures. International Journal of Entrepreneurship and Innovation Management, 13(1), 12-31.

Henley, A. (2005). Job creation by the self-employed: The roles of entrepreneurial and financial capital. Small Business Economics, 25, 175-196.

Hjorth, D., \& Holt, R. (2016). It's entrepreneurship, not enterprise: Ai Weiwei as entrepreneur. J Business Venturing Insights, 5, 50-54.

Hughes, M., \& Morgan, R. E. (2007). Deconstructing the relationship between entrepreneurial orientation and business performance at the embryonic stage of firm growth. Industrial Marketing Management, 36, 651-661.

Institute for Business Studies and Research (2005). The role of clustering in increasing the competitiveness of small and medium-sized enterprises with a focus on marketing development.

Ireland, D. R., Hitt, M. A., \& Sirmon, D. G. (2003). A Mmodel of strategic entrepreneurship: The construct and its dimensions. Journal of Management, 29(6), 963-989.

Iversen, J., Jorgensen, R., \& Malchow-Moller, N. (2008). Defining and measuring entrepreneurship. Foundations Trends Entrepreneur, 4(1), 1-63.

Izadi, H., \& Rezaei-Moghaddam, K. (2017). Accelerating components of the entrepreneurship development in small agricultural businesses in rural areas of Iran. Technical Journal of Engineering and Applied Sciences, 7(1), 6-15. 
Izadi, H., Rezaei-Moghaddam, K., \& Asadollahpour, A. (2016). Influencing factors and the obstacles for accomplishing of entrepreneurship development in agricultural home-based businesses in the villages of shiraz. Iran Agricultural Extension Edu J, 12(1), 39-51.

Kamunge, M. S., Njeru, A., \& Tirimba, O. I. (2014). Factors affecting the performance of small and micro enterprises in Limuru town market of Kiambu County Kenya. Int J Sci Res Pub, 4(12), 1-20.

Khodamipour, A., \& Shafiei, H. (2013). Company sustainability and measurement. Auditor's Monthly, 69, 1-5.

Kickul, J., Gundry, L. K., Barbosa, S. D., \& Whitcanack, L. (2009). Intuition versus analysis? Testing differential models of cognitive style on entrepreneurial self-efficacy and the new venture creation process. Entrepreneurship Theory and Practice, 33(2), 439-453.

Krejcie, R. V., \& Morgan, D. W. (1970). Determining sample size for research activities. Educational and Psychological Measurement, 30(3), 607-610.

Lee, L., and Wong, P. K. (2006). How does an entrepreneur's ability influence the propensity to exploit novel opportunities? The moderating role of personality and environment. MPRA Paper No. 597. Online at https://www. researchgate.net/profile/Poh_Kam_Wong/publication/24114703_How_does_An_Entrepreneur\%27s_Ability_Influence_ the_Propensity_to_Exploit_Novel_Opportunities_The_Moderating_Role_of_Personality_and_Environment/links/ Ofcfd50fb68e01 b572000000/How-does-An-Entrepreneurs-Ability-Influence-the-Propensity-to-Exploit-NovelOpportunities-The-Moderating-Role-of-Personality-and-Environment.pdf?origin=publication_detail. Posted 26. October 2006/22:38.

Lerner, M., Brush, C., \& Hisrich, R. (1997). Israeli women entrepreneurs: An examination of factors affecting performance. Journal of Business Venturing, 12(4), 315-339.

Metcalfe, J. S. (2004). The entrepreneur and the style of modern economics. Journal of Evolutionary Economics, 14, 157-175.

Ministry of Jihad Agriculture of Iran (2018). Agricultural conversion and complementary industrie. Retrieved from https://maj. ir/index.aspx?lang $=2 \&$ sub $=0$ and lang.

Mollashahi, G. A., Zarifian, S., \& Sarani, W. (2014). Factors affecting the achievement of small and medium crops and gardens in Zabol. Iranian J Agricultural Econ Dev, 46(4), 739-748.

Mostofi, M. R., \& Abbasi, A. (2010). Investigating the realization of goals in the design of early enterprises in Qom Province. J Financial Stud, 7, 165-189.

Olawale, F., \& Garwe, D. (2010). Obstacles to the growth of new SMEs in South Africa: A principal component analysis approach. African Journal of Business Management, 4(5), 729-738.

Parsa Pour, S., Barati, J., \& Rasoulzadeh, M. (2012). Factors affecting the sustainability of small firms and entrepreneurs case study: Industrial enterprises of Mashhad city. Entrepreneur Dev, 10(1), 41-60.

Rezaei, R., \& Safa, L. (2016a). Study on development barriers of agricultural early return and entrepreneurship small and medium enterprises in Zanjan province. Iranian J Agricultural Econ Dev Res, 47(1), 67-79.

Rezaei, R., \& Safa, L. (2016b). Factors affecting the development of small and medium enterprises in Zanjan province. J Rural Space Rural Dev, 5(18), 141-163.

Sahraeian, S. M. (2001). Iranian economy organizes small industries. Tehran: Education Publications.

Saleh, A. S., \& Ndubisi, N. O. (2006). An evaluation of SME development in Malaysia. Int Rev Business Res Papers, 12(1), 1-14.

Scheiner, C. W. (2014). The role of recognition intelligence for opportunity recognition of habitual entrepreneurs. Problem Perspective Manag, 12, 60-71.

Shane, S. (2000). Prior knowledge and the discovery of entrepreneurial opportunities. Organization Science, 11(4), 448-469.

Sharifzadeh, A., Arabioun, A., \& Abdollahzadeh, G. H. (2009). Identify and prioritize the support needs of agricultural business development. Entrepreneur Dev, 3(10), 71-91.

Sherazi, S. K., lqbal, M. Z., Asif, M., Rehman, K., \& Hussain Shah, S. S. (2013). Obstacles to small and medium Enterprises in Pakistan Principal Component Analysis Approach. Middle East J Sci Res, 13(10), 1325-1334.

Sidik, I. G. (2012). Conceptual framework of factors affecting SME development: Mediating factors on the relationship of entrepreneur traits and SME performance. Proc Econ Finance, 4, 373-383.

Simsek, Z., \& Heavey, C. (2011). The mediating role of knowledge-based capital for corporate entrepreneurship effects on performance: A study of small-to medium-sized firms. Strategic Entrepreneurship Journal, 5, 81-100.

Soltani, Z., Khoshnod, Z., \& Akbari Alashti, T. (2012). Financial mechanisms of small and medium enterprise. Research Report, Monetary and Banking Research Institute. Tehran: Central Bank of the Islamic Republic of Iran.

Tåg, J., Åstebro, T., and Thompson, P. (2016). Hierarchies and entrepreneurship. https://doi.org/10.1016/j.euroecorev. 2016.06.007.

Talebi, K. (2007). Strategic role of small and medium enterprises in national development. Tehran. Tehran: University Press.

Tambunan, T. (2008). Trade liberalization effects on the development of small and medium-sized enterprises in Indonesia: A case study. Asia Pacific Dev J, 15(2), 21-35.

Thurik, R., \& Wennekers, S. (2004). Entrepreneurship, small business and economic growth. J Small Business Enterprise Dev, 11(1), 140-149.

Tumasjan, A., \& Braun, R. (2012). In the eye of the beholder: How regulatory focus and self-efficacy interact in influencing opportunity recognition. Journal of Business Venturing, 27(6), 622-636.

Unidro. (2003). The strategy of increasing the effective and competitive participation of small and medium industries in the economic and industrial development of the Islamic Republic of Iran. Translator: Shaghaghi, Abdolreza and Shafiee, Massoud (1st ed.). Tehran: Rasa cultural institute.

Urbano, D., \& Aparicio, S. (2016). Entrepreneurship capital types and economic growth: International evidence. Technological Forecasting and Social Change, 102, 34-44.

Vahdat, D., \& Dadashi, A. (2010). A look at the plan to support the expansion of early-stage economic enterprises and some of its implementation shortcomings. J Parks Growth Centers, 7(25), 15-24.

Wang, M. C., \& Fang, S. C. (2012). The moderating effect of environmental uncertainty on the relationship between network structures and the innovative performance of a new venture. J Business Industrial Market, 27(4), 311-323.

Wang, X., Jessup, L. M., \& Clay, P. F. (2015). Measurement model in entrepreneurship and small business research: A ten year review. International Entrepreneurship and Management Journal, 11, 183-212. 
Wiklund, J., \& Shepherd, D. (2005). Entrepreneurial orientation and small business performance: A configurational approach. Journal of Business Venturing, 20, 71-91.

Yeh-Yun, L., \& Zhang, J. (2005). Changing structures of SME networks: Lessons from the publishing industry in Taiwan. Long Range Planning, 38, 145-162.

Zaridis, A. D., \& Mousiolis, D. T. (2014). Entrepreneurship and SME's organizational structure. Elements of a successful business. Procedia-Social and Behavioral Sciences, 148, 463-467.

Submit your manuscript to a SpringerOpen ${ }^{\circ}$ journal and benefit from:

- Convenient online submission

Rigorous peer review

- Open access: articles freely available online

High visibility within the field

- Retaining the copyright to your article

Submit your next manuscript at $\boldsymbol{\nabla}$ springeropen.com 